1 Sonja Siljak-Yakovlev ${ }^{1 *}$, Françoise Lamy, ${ }^{1,2}$, Najat Takvorian ${ }^{1,3}$, Nicolas Valentin ${ }^{4}$, 2 Valérie Gouesbet ${ }^{5}$, Françoise Hennion ${ }^{5}$, Thierry Robert ${ }^{1,3}$

3

4

5

6

7

8

9

\title{
Genome size and chromosome number of ten plant species from Kerguelen
} Islands

${ }^{1}$ Université Paris-Saclay, CNRS, AgroParisTech, Ecologie Systématique Evolution, 91405, Orsay, France

${ }^{2}$ Université Versailles-Saint-Quentin, département de Biologie, 45 bd des Etats-Unis, 78035 Versailles, France

${ }^{3}$ Sorbonne Université, UFR 927, 4 Place Jussieu, F-75252 Paris Cedex 05, France

${ }^{4}$ Institute of Integrative Biology of the Cell (I2BC), CEA, CNRS, Université Paris-Saclay, 91198, Gif-sur-Yvette, France

${ }^{5}$ Ecosystèmes, Biodiversité, Evolution, UMR 6553 ECOBIO, Université de Rennes 1, OSUR, CNRS, F-35042 Rennes, France

*Correspondence: E-mail: sonia.yakovlev@u-psud.fr, sonia.yakovlev@universite-parissaclay.fr

ORCID : 0000-0002-6247-3351

\section{Order of authors secondary information:}

Françoise Hennion contributed as senior authors on this paper.

\section{Acknowledgement}

The present research project No 1116 PlantEvol (resp. F. Hennion) was performed at Kerguelen station and was supported by the French Polar Institute (IPEV). This research was also supported by CNRS IRP grant “AntarctPlantAdapt” (F. Hennion). We thank B. Labarrere, L. Marchand (UMR ECOBIO, Rennes, France) and G. Bouger (UMS OSUR, Rennes, France), V. Normand (UMR ESE, Orsay, France), K. Delord (Centre d'études biologiques de Chizé, CNRS, France), IPEV logistics, and Réserve naturelle Terres Australes et Antarctiques françaises for help in material collection during the summer campaigns (20152019). We thank Experimental Ecology platform (ECOLEX) of Ecobio lab, T. FontaineBreton, F. Nassur and R. Bodiguel for help in plant cultivation in the phytotron, T. FontaineBreton and O. Lima for leaf collection for flow cytometry. The authors thank B. Robert for his help in statistical analyses and Dr. M. Bourge for his expert assistance in flow cytometry on the Platform of Cytometry, Institute of Integrative Biology of the Cell (I2BC), Gif-surYvette. Finally, we would like to thank Dr Dieter Piepenburg, Editor-in-chief of Polar Biology and three reviewers (Dr Joan Vallès, Dr Teresa Garnatje and one anonymous reviewer) for their constructive comments that have fully contributed to improving our manuscript. 


\section{Abstract}

Kerguelen Islands harbor a unique and probably ancient flora with a high rate of endemism. However, few is known on evolutionary history and characteristics of this flora. This concerns in particular genome size and ploidy level variation, despite the evolutionary and ecological significance of those traits. Here we report the first assessment of genome size, using flow cytometry, for eight plant species of which two are endemics of Kerguelen Islands and four of the South Indian Ocean Province. The 2C DNA value ranged from $1.08 \mathrm{pg}$ for Pringlea antiscorbutica to $11.88 \mathrm{pg}$ for Ranunculus biternatus. The chromosome numbers of Colobanthus kerguelensis $(2 n=80)$, Lyallia kerguelensis $(2 n=96)$ and Poa kerguelensis $(2 n$ $=28$ ), were also reported in this study for the first time. Overall, our data allowed to infer that all Kerguelen studied species are polyploid (from tetra to octopolyploid). Intra-genus comparisons showed significant differences of 2C DNA values among Poa and among Ranunculus species, despite their identical ploidy levels. In addition, our data highlight the existence of an intraspecific variability of genome size for the two octoploid species Colobanthus kerguelensis and Lyallia kerguelensis. Finally, our data also support the hypothesis according which polyploidy may have played a major role in the adaptation of flowering plants to high latitudes, as it has been suggested for arctic species.

Keywords 2C DNA value • Endemic species • Flow cytometry • Genome size • Ploidy level - sub-Antarctic flora

\section{Introduction}

The sub-Antarctic islands (sensu Smith 1984; Van der Putten et al. 2010) host a depauperate angiosperm flora of about 58 taxa. These islands were very early suggested to be important in the floristic history of the Southern Hemisphere as possible stepping-stones for dispersal or refuges for plant species during glacial times (e.g., Hooker 1847; Werth 1911; Hennion and Walton 1997; Chown et al. 2001; Van der Putten et al. 2010). However, the evolutionary histories of sub-Antarctic plant taxa have so far been little studied (Winkworth et al. 2015; Lehnebach et al. 2017). The sub-Antarctic plants are already feeling the impacts of contemporary climate change (Le Roux et al. 2005; Frenot et al. 2006; Bergstrom et al. 2015). This situation appeals urgently for deeper insights into biological and genetic characteristics of native species that may contribute to their adaptation to this harsh environment and possibly to their resilience to climate change.

The Kerguelen Islands that appeared 29 Ma ago (Nicolaysen et al. 2000), are one of key sites for addressing both the history and future of the sub-Antarctic flora. Some species may have been long present on the islands and survived Pliocene-Pleistocene climate change in situ (e.g., Wagstaff and Hennion 2007; Bartish et al. 2012) while others may be the result of more recent, perhaps Holocene, colonisation (Lehnebach et al. 2017). While most previous studies addressed morphological variability, ecology and ecophysiology of these species (Hennion et al. 2012; Hermant et al. 2013; Labarrere et al. 2019), very little is known about the characteristics of their genome and especially their genome size. 
Genome size (2C-value) or amount of DNA in a somatic unreplicated nucleus (Swift 1950; Greilhuber et al. 2005) is one of the most fundamental biological characters of living organisms and it is frequently correlated with many biotic and abiotic parameters (Bennett and Leitch 2005; Pustahija et al. 2013). Two processes are responsible for differences in genome size and complexity. One is change in monoploid genome size 1Cx (DNA content of a monoploid genome with chromosome base number $x$, according to Greilhuber et al. 2005) due to variation in the copy number of genetic elements after duplication or deletion events. The other involves whole genome duplication or polyploidization. Knowledge on genome size is useful in many disciplines such as ecology and phytogeography (Grime and Moworth 1982; Price and Johnston 1996; Pustahija et al. 2013), systematics and evolution (Cerbah et al. 1999; Niketic et al. 2013; Hajrudinovic et al. 2015), in biotechnology and agronomical sciences (Fyad-Lameche et al. 2016; Srisuwan et al. 2019) and also in biodiversity screening (Bennett et al. 2000; Siljak-Yakovlev et al. 2010; Bou Dagher-Kharrat et al. 2013; SiljakYakovlev et al. 2019).

Among the different methods for estimating genome size, flow cytometry is now the most currently used (Marie and Brown 1993; Doležel et al. 2007; Pellicer and Leitch 2014; Bourge et al. 2018). This method is rapid, precise, easy for sample preparation and accurate for detection of small differences in DNA content (Karrat-Souissi et al. 2013; Pellicer and Leitch 2014). Despite its biological relevance, genome size has been estimated for only $3.1 \%$ of all angiosperms and $41 \%$ of gymnosperms (Pellicer et al. 2018).

The chromosome number is also one of relevant biodiversity characters (Guerra 2008) that has been considered in this work.

The present work mainly aims to study the interspecific variability of genome size, chromosome number and ploidy levels of ten Kerguelen species including two strictly endemic species (Lyallia kerguelensis and Ranunculus moseleyi) and four other species endemic to the South Indian Ocean Province (Colobanthus kerguelensis, Poa cookii, Poa kerguelensis and Pringlea antiscorbutica). At the same time, it is a first step in building a genome size database for plants from the Kerguelen Islands.

\section{Materials and methods}

\section{Plant material}

Plant material from ten species were collected from natural populations in Kerguelen Islands over 3 field campaigns between 2015 and 2019 (Table 1, Fig. 1). The studied species belong to six families and six genera. Nine of them were native to Kerguelen Islands whereas Poa annua was an introduced one (Table 1). Lyallia kerguelensis and Ranunculus moseleyi are strictly endemic to Kerguelen (Hennion and Walton 1997; Lehnebach et al. 2017). Colobanthus kerguelensis, Poa cookii, Poa kerguelensis and Pringlea antiscorbutica are endemic to the South Indian Ocean Province (SIOP) that includes Kerguelen, Marion and Prince Edward Islands, Crozet, and Heard (Smith 1984; Van der Putten et al. 2010). Except for Limosella australis at least three populations per species were studied.

During the field work the plant material (leaves) was immediately dried and conserved in silica gel until use. Living plants were stored in zip-lock plastic bags then potted at 
Kerguelen station. After a few weeks, living plants were shipped back to metropolitan France and cultivated in a phytotron in CNRS-UMR 6553 ECOBIO, University of Rennes 1 (Ecolex facility). Root tips for karyological analyses and leaves for genome size studies were sampled from these plants in cultivation. Seeds of $C$. kerguelensis were collected from one population in Pointe Suzanne in April 2017 and seeds of L. kerguelensis. from two populations in Ile Australia in March 2019. Seeds were placed in paper bags, let dry a few days at room temperature then stored in the presence of silica gel until use. The seeds of both species were germinated in the lab at $20^{\circ} \mathrm{C}$ (Hennion and Walton 1997). Vouchers of the studied populations are available in CNRS-UMR 6553 ECOBIO, University of Rennes 1, and in CNRS-UMR 8079 ESE, University Paris-Saclay.

\section{Genome size estimation by flow cytometry}

The total nuclear DNA amount (2C-value) was assessed by flow cytometry according to Bourge et al. (2018) using fresh or silica dried leaf samples and fresh leaves of one of four internal standards, in order to cover the range of variation of genome size: Solanum lycopersicum L. 'Montfavet 63-5' (2C = 1.99 pg, Lepers-Andrzejewski et al. 2011) for very small genomes, Petunia hybrida Vilm. 'PxPc6' (2C = 2.85 pg, Marie and Brown 1993) for small genomes and Hordeum vulgare L. 'Sultan' (9.81 pg, Garnatje et al. 2004) for intermediate genome size. A first genome size measurement was performed on fresh material collected from seven species cultivated at Ecolex facility in CNRS-UMR 6553 ECOBIO, University of Rennes 1 (Table 2). To test the reliability of genome size assessment on silica gel-dried material, parts of each fresh leaf sample were dried in silica gel before measurement and the results of genome size measurements were compared in samples conditioned either way.

The leaves of both internal standard and target species were simultaneously chopped using a razor blade in a sterile plastic Petri dish with $600 \mu \mathrm{l}$ of cold Gif Nuclear-isolation Buffer (GNB) which has been previously successfully tested on many dried samples (Razafinarivo et al. 2012), both on angiosperms and gymnosperms (Siljak-Yakovlev et al. 2019 and Farhat et al. 2019a respectively). This buffer contains $45 \mathrm{mM} \mathrm{MgCl}$, $30 \mathrm{mM}$ sodium citrate and $60 \mathrm{mM}$ MOPS acid pH 7.0, 1\% PVP 10.000 and $10 \mathrm{mM}$ sodium metabisulfite $\left(\mathrm{Na}_{2} \mathrm{~S}_{2} \mathrm{O}_{5}\right)$, a reducing agent less toxic than $\beta$-mercaptoethanol, and RNAse (2.5 $\mathrm{U} / \mathrm{ml}$ ). It was also complemented with $0.5 \%$ Triton X-100. The nuclei suspension was filtered through (30 or $50 \mu \mathrm{m}$ nylon) mesh. The nuclei were stained with $100 \mu \mathrm{g} / \mathrm{ml}$ propidium iodide (PI), a specific DNA intercalating fluorochrome dye, and kept at least $5 \mathrm{~min}$ at $4^{\circ} \mathrm{C}$.

DNA content of about 5000 stained nuclei was determined for each sample using the cytometer CytoFLEX S with excitation $561 \mathrm{~nm}, 26 \mathrm{~mW}$ and emission through a 610/20 nm band-pass filter (Beckman Coulter- Life Science United States). The samples for each species, except for Limosella australis, comprised at least five individuals, measured separately. To check the reproducibility of values, two replicates were performed for each individual.

CytExpert 2.3 software was used for histogram analyses. The total 2C DNA value (DNA contents of the diploid (2n) sets of chromosomes, irrespective of ploidy level), was calculated using the linear relationship between the fluorescent signals from stained nuclei of 
the species and the internal standard. The total nuclear DNA content was calculated according to the following formula:

2C DNA sample $(\mathrm{pg})=($ Sample 2C peak mean/Standard 2C peak mean $) \times$ Standard 2C DNA (pg)

The symbol C corresponds to the holoploid nuclear genome size (the whole chromosome complement with chromosome number $n$ in mitotic nuclear cycle), 1C DNA content presents one non-replicated holoploid genome with the chromosome number $n$ and 2C DNA value corresponds to somatic chromosome number (2n), irrespective of ploidy level (Greilhuber et al. 2005).

To check existing data and assign the status of newness for our reports, we used, apart from bibliography for each species, existing genome size and chromosome number databases, all of them accessed on January 25, 2020: Plant DNA C-values database (http://data.kew.org/cvalues), FLOWer, a plant DNA flow cytometry database (http://botany.natur.cuni.cz/flower/index.php), the Chromosome count database CCDB (http://ccdb.tau.ac.il/), the Index to Plant Chromosome Numbers (IPCN, www.tropicos.org/) and the Brassicaceae: Chromosome number index (warwick_chrmno_data_xls).

\section{Chromosome number determination}

Root tips obtained from the potted plants cultivated in University of Rennes 1, CNRS-UMR 6553 ECOBIO, or by germination of seeds (case of Colobanthus kerguelensis and Lyallia kerguelensis), were pretreated with $0.05 \%$ colchicine aqueous solution at room temperature from $1 \mathrm{~h} 30$ to $3 \mathrm{~h}$ or in 8-hydroxyquinoline $0.002 \mathrm{M}$ during $2-3 \mathrm{~h}$ at $16^{\circ} \mathrm{C}$ and then fixed in absolute ethanol and glacial acetic acid (3:1) for at least two days at $4{ }^{\circ} \mathrm{C}$. Root tips were hydrolyzed in $1 \mathrm{M} \mathrm{HCl}$ for 6 to $12 \mathrm{~min}$ at $60{ }^{\circ} \mathrm{C}$, washed in distilled water at room temperature, and stained in $1 \%$ orcein in $45 \%$ acetic acid for about $30 \mathrm{~min}$. Root tip meristems were squashed in a droplet of acetic carmine and observed under Zeiss Axiophot microscopes. The best metaphase plates were photographed using CCD camera (RETIGA 2000R; Princeton Instruments, Evry, France).

\section{Data analyses}

Statistical analyses were carried out on the whole data set except for Limosella australis since only one sampled individual was available. Genome size variation was analyzed as described in the following. For each species, non-parametric Fligner test was used to check for rank variance homogeneity among populations. Non-parametric Kruskall-Wallis statistics were used to test for significant variation of genome size among populations within species. In addition, and because of small sample size, 10000 random permutations of individuals among population (within species) were also used to compute each p-value in order to confirm the conclusion for the significance of the population effect of the Kruskall-Wallis statistics using an independent test. For species showing a significant population effect, post-hoc nonparametric tests (Dunn, 1961) were used for population median pairwise comparisons. Finally, for the three Poa species and the three Ranunculus species, differences of genome 
size among species within each genus were tested using two independent methods. Firstly, a nested two-way analysis of variance was carried out on rank values of genome size to test for comparisons among species and among populations as a potential dependence random factor nested within species after testing for variance homogeneity using a Levene's test. The population mean square was used as the error term to test for species difference. Adjusted pvalues for multiple tests were computed according to Holm's method. Secondly, a nonparametric Kruskall-Wallis test was also carried out on genome size values to test for differences among populations (population factor nested within the species factor) as described in Oron and Hoff (2006) and among species. Then, a Kruskall-Wallis test was carried out on genome size values to test for significant differences among species. The pvalue for the species effect was then computed using permutation of populations among species (1000 random permutations). Pairwise comparisons of median species differences were carried out using a Dunn test (Dunn, 1961) using a Holm correction for multiple test (Holm, 1979).

\section{Results}

The results on genome size assessment on fresh and dry materials did not show any significant differences. Therefore, only the results obtained on the dry material are presented.

\section{Variation of genome size among and within species}

The genome size ranged from $2 \mathrm{C}=1.08 \mathrm{pg}$ for Pringlea antiscorbutica to $2 \mathrm{C}=11.88 \mathrm{pg}$ for Ranunculus biternatus. According to Leitch's et al. (1998) categories, the ten species displayed very small (2C < 2.8 pg; Colobanthus kerguelensis, Limosella australis and Pringlea antiscorbutica), small $(2.8 \leq 2 \mathrm{C}<7$; Lyallia kerguelensis and three Poa species) or intermediate ( $\leq 2 \mathrm{C}<28$; three Ranunculus species) genome size (Table 2). No species with large $(28 \leq 2 \mathrm{C} \leq 75)$ or very large $(2 \mathrm{C}>75 \mathrm{pg})$ genome size were found in the studied material.

For intra-genus comparisons, analyses of variance using rank values as well as permutation tests showed significant differences of 2C values among Poa species $(F=$ 167.64, $d f=(2 ; 6), p$-value $<0.0001 ; H=39.10, p$-value $<0.001$ (permutation test) and among Ranunculus species $(F=9.64, d f=(2 ; 6)$, $\mathrm{p}$-value $=0.013 ; H=12.82, p$-value $=0.016$ (permutation test), despite identical ploidy levels within each genus.

In Ranunculus genus, post-hoc pairwise comparisons showed $R$. biternatus displayed a significantly higher genome size than the two other Ranunculus species. In Poa genus, post hoc pairwise comparisons between species were all highly significant.

For Pringlea antiscorbutica, the three Poa and the three Ranunculus species, no significant differences in 2C values among populations were observed. However, genome size varied significantly among populations of Lyallia kerguelensis (9.9\% of population mean variation) and of Colobanthus kerguelensis (7.9\% of population mean variation). For these two species, post-hoc pairwise comparisons showed that the population RBA10 for $C$. kerguelensis and the population MAC3 for L. kerguelensis displayed significantly smaller genomes than other populations from the same species. 


\section{Chromosome number and estimation of ploidy levels}

The results of chromosome counts and ploidy levels of studied species are presented in Table 2 and Fig. 2. The high chromosome number and basic chromosome number of each genus strongly supported the polyploid status of all investigated species. The chromosome numbers of Colobanthus kerguelensis $(2 n=8 x=80)$, Lyallia kerguelensis $(2 n=8 x=96)$ and Poa kerguelensis ( $2 n=4 x=28)$ are reported here for the first time, as well as for Limosella australis $(2 n=6 x=60)$ from Kerguelen.

\section{Discussion}

\section{Chromosome number and ploidy level}

In this study chromosome numbers and ploidy levels were reported for the first time for three endemic species from Kerguelen or from the SIOP (Lyallia kerguelensis, Poa kerguelensis, Colobanthus kerguelensis) and for Limosella australis from Kerguelen.

Data relative to the ploidy level of species occurring in the sub-Antarctic region are yet limited except from the study of Bennett et al. (1982) concerning South Georgia. The Arctic region was shown to harbor a high occurrence of polyploid species (Brochmann et al. 2004). These authors also indicated that number and ploidy level strongly increased when going northwards in the Arctic region. Our data suggest that polyploidy may also be highly frequent in plant species living in high south latitudes.

We confirmed the tetraploid chromosome numbers $(2 n=4 x=28)$ for Poa annua previously reported in Kerguelen by Frenot et al. (1999). Only three reports on diploid ( $2 n=$ $14)$ in Slovakia, Australia and North India and two on hexaploid $(2 n=6 x=42) P$. annua populations in China and Pakistan were indicated until now (Dhaliwal et al. 2018). In numerus other areas across the world (at least 16 bibliographic references) this species occurs as tetraploid in Kerguelen. Poa annua's introduction in Kerguelen is believed to be fairly recent, contemporary to first human visits on the island (first record in 1874 by Moseley; in Frenot et al. 1999). Therefore, it appears that the chromosome number and the ploidy level of Poa annua have not changed subsequently to its introduction. We confirmed the chromosome number of $2 n=4 x=28$ for Poa cookii (Hennion 1992).

Polyploidy or whole genome multiplication (WGM) is considered as one of major evolutionary forces in angiosperm evolution (Solstis and Solstis 2009). Possibly all angiosperms had at least one WGD during their evolutionary history (Van de Peer et al. 2017). In our panel all species are polyploid with different ploidy levels. Colobanthus kerguelensis and Lyallia kerguelensis showed the highest ploidy level (octoploid), three Ranunculus species and Limosella australis are hexaploids, and Pringlea and three Poa species are tetraploids.

In most reports so far $L$. australis presents the diploid chromosome number $(2 n=20)$ except in New Zealand where it is hexaploid $(2 n=60)$ as it was found in this study for the Kerguelen population (Blackburn 1939; Löve and Löve 1958; Hair and Beuzenberg 1960; Dawson 2000).

The case of Pringlea antiscorbutica is especially appealing. We confirmed the chromosome numbers $(2 n=24)$ previously established for this species (Hamel 1951; Rollins and Rüdenberg 1971; Hennion and Couderc 1992; Kagale et al. 2014). This species is known to have diverged from a South American ancestor about 5 Mya ago (Bartish et al. 2012), but it 
is not known whether it dispersed directly to the SIOP or whether Antarctica could be used as a stepping-stone (Bartish et al. 2012). This species displayed the smallest chromosome number $2 n=24$, corresponding also to the smallest genome size $(2 \mathrm{C}=1.08 \mathrm{pg})$. In their study on polyploid evolution using transcriptomic data in Brassicaceae, Kagale et al. (2014) proposed that Pringlea antiscorbutica is a mesopolyploid ( 10.22 Mya). Regarding the basic chromosome numbers referenced in the Brassicaceae family (Kagale et al. 2014), Pringlea could, at least, be considered as tetraploid with a basic chromosome number $x=6$. Alternatively, it could be a hexaploid with $x=4$, which is the smallest basic chromosome number of Brassicaceae, according to Lysak et al. (2006). Interestingly, Kagale et al. (2014) dated the few major polyploidy and lineage separation events they identified during Brassicaceae evolution around epoch transitions characterized by prolonged unstable climatic conditions. These authors suggested that polyploidy might have increased tolerance of Brassicaceae to these changes and facilitated species radiation. This might indeed be the case for $P$. antiscorbutica which speciation estimated time is contemporary to climate cooling in the southern landmasses and in Antarctica (Bartish et al. 2012).

We confirmed the chromosome numbers and ploidy levels $(2 n=6 x=48)$ for the three Ranunculus species previously reported in Kerguelen by Hennion and Couderc (1992, 1993) and by Bennett et al. (1982) for R. biternatus from south Atlantic island South Georgia.

\section{Genome size variation among species}

Data given in Table 2 are the first report on genome size for plant species growing in Kerguelen Islands except for Poa annua which was already measured from Crozet and Kerguelen by Frenot et al. (1999). The genome size was also already reported for Ranunculus biternatus but from South Georgia by Bennett et al. (1982).

A 11-fold variation was found between the lowest 2C value, $1.08 \mathrm{pg}$ for Pringlea antiscorbutica, and the highest 2C value, 11.88 pg for Ranunculus biternatus. However, seven of these ten species belong to groups of very small $(2 \mathrm{C}<2.8 \mathrm{pg})$ or small $(2.8 \leq 2 \mathrm{C}<7 \mathrm{pg})$ genome size, according to Leitch et al. (1998) categories. The remaining three species (Ranunculus ssp.) displayed an intermediate genome size $(7 \leq 2 \mathrm{C}<28)$. This finding supports the idea that species living at high latitudes have, in general, a small genome (Bennett et al. 1982; Brochmann et al., 2004). This trend could be related to the need for plants living in these regions to cope with short growing periods. Cell cycle length and growing periods are in general shorter in plants with small genome (Bennett 1972, 1987; Beaulieu et al. 2008). It has also been shown that these characteristics are favoured in hostile environments, in particular, under temperature, water and nutritional stresses (low concentrations of macronutrients) (Petrov 2001; Šmarda et al. 2013; Guignard et al 2016; Pellicer et al. 2018).

By their large genome constraint hypothesis, Knight et al. (2005) designed that plants with large genomes are under-represented in extreme environments. Many example (Pustahija et al. 2013; Carta and Peruzzi 2015) even among aquatic plants (Hidalgo et al. 2015) illustrated this general trend. Results obtained in this study also supports this hypothesis in extreme climatic conditions which occur in the sub-Antarctic region.

For Poa annua, Bennett (1982) indicated almost the same value as in the present study, $2 \mathrm{C}=4.19( \pm 0.06) \mathrm{pg}$. However, Frenot et al. (1999) reported a much smaller value of $2.95( \pm$ 0.14) $\mathrm{pg} / 2 \mathrm{C}$ for populations from French sub-Antarctic islands (Crozet and Kerguelen), 
although the chromosome number $(2 n=28)$ was identical to the one reported here. However, the data obtained by these authors corresponded to relative DNA content because they used DAPI (4',6-diamidino-2-phenylindole), fluorochrome specific for A-T bases, which, in general, provides lower values than propidium iodide (DNA intercalating fluorochrome).

The value of relative $1 \mathrm{C}$ reported for Pringlea antiscorbutica $(1 \mathrm{C}=0.62 \mathrm{pg})$ by Kagale et al. (2014) for material from Botanical Garden (Canberra, Australia) originally collected from Heard Island, is very close to the mean value $(2 \mathrm{C}=1.08 \mathrm{pg})$ estimated on samples from Kerguelen populations.

Ranunculus biternatus is spread across the whole circumpolar area (Lehnebach et al. 2017). Bennett et al. (1982) reported 2C $=14.50 \mathrm{pg}$ for $R$. biternatus from South Georgia, a sub-Antarctic island in the South Atlantic Ocean. The present value obtained for this species was much smaller $(2 \mathrm{C}=11.88+0.23 \mathrm{pg})$. Variation in ploidy level cannot be invoked to explain this result since the chromosome counts $(2 n=48)$ are identical for both origins (Bennett et al. 1982; Hennion and Couderc 1993; this work). This result could be explained by the use of two different techniques of genome size assessment (Feulgen densitometry by Bennett et al. 1982, and flow cytometry in our case). Alternatively, this result could reflect a true difference in genome size between populations of this species in the two locations.

It should be noted that the Ranunculus biternatus lineage is sister to a clade of species from Australia and New Zealand, with estimates indicating very recent spread to Crozet and Kerguelen (Lehnebach et al. 2017). Therefore, populations from South Georgia, close to the magellanics, may be only distantly related to the populations of the same species in Kerguelen. A larger sampling effort of $R$. biternatus across its geographic range is required to investigate genome size variability in this species.

Comparisons of genome size among the three Ranunculus species revealed that $R$. biternatus displayed a significantly higher genome size than the two other Ranunculus species (R. pseudotrullifolius and the endemic $R$. moseleyi) which did not differ one from each other. This last result is in agreement with the hypothesis of a very recent divergence between these last two species (Hennion et al. 1994; Lehnebach et al. 2017). Another explanation would be that genome size of these two species might be the target of stabilizing selection, at least since their divergence, which would maintain similar genome size values (Šmarda et al. 2010). Contrarily, $R$. biternatus has been shown to belong to a clearly different evolutionary lineage than $R$. moseleyi and R. pseudotrullifolius (Lehnebach et al. 2017). This is in agreement with a significant difference in the genome size of these two taxa on one side and $R$. biternatus on the other side.

Colobanthus kerguelensis showed 2C value of $2.41( \pm 0.08) \mathrm{pg}$. This value is higher than all values reported for the congeneric $C$. quitensis, a very wide-ranged species inhabiting extreme environments in Antarctica and the Andes and rarer locations northwards (Cuba-Diaz et al. 2017). Indeed, Bennett et al (1982) reported 2C $=1.4 \mathrm{pg}$ for one population of $C$. quitensis in South Georgia. Moreover, Cuba-Diaz et al. (2017) determined 2C = 1.95 in two populations of $C$. quitensis (King George Islands in the maritime Antarctic and one location in Patagonia) and 2C $=0.84 \mathrm{pg}$ in one population from Araucania region, growing in a more temperate zone and at high altitude (2575 $\mathrm{m}$ a.s.l.). The more than twofold difference in genome size between the two populations of C. quitensis studied by Cuba-Diaz et al. (2017) strongly suggests the existence of at least two ploidy levels in this species. Unfortunately, the 
record of chromosome number in C. quitensis is limited to the data reported in Bennett et al. (1982) which is identical to the count obtained for C. kerguelensis in this study $(2 n=80)$. More detailed cytogenetic studies are needed in populations of $C$. kerguelensis across the SIOP and C. quitensis across Antarctica and South America to get a more comprehensive view of the variations in genome size in these two species.

\section{Intraspecific variation of genome size at Kerguelen}

Whether intraspecific genome size constancy is mainly due to balance between sequences gain/loss events (Petrov 2002) or is the target of stabilizing selection (Waltari and Edwards 2002; Šmarda et al. 2010.) is still being debated. However, more recently, studies aiming at assessing the intraspecific genome size variability suggest it may have been widely underestimated until a recent past (Vekemans et al. 1996; Šmarda and Bureš 2006; Suda et al. 2007; Siljak-Yakovlev et al. 2008; Karrat-Souissi et al. 2013; Abdeddaim-Boughanmi et al. 2019; Farhat et al. 2019b).

No significant variation of genome size was observed among Kerguelen populations studied for Pringlea antiscorbutica, for the three Poa species and for the three Ranunculus species. It is however possible that interpopulation variation exists in those species but was not detected in this study due to the limited number of sampled populations.

In contrast, significant variation in genome size was observed among studied populations in Lyallia kerguelensis and in Colobanthus kerguelensis. In L. kerguelensis the population MAC3 (located in the north of Kerguelen) differed significantly from the other two populations due to its smallest 2C DNA values (Table 2). In Colobanthus kerguelensis, the population of Rallier du Baty differed significantly from the other three populations. The history of glacier extent at Kerguelen may explain this last result. Indeed, the south-west region including Péninsule Rallier du Baty was partially isolated from the rest of the main Kerguelen land during last millennia by several glaciers contributing to the Calotte Cook (Jomelli et al. 2018). Further investigations are needed to get better insights into the geographic patterns of intraspecific genome size variation across Kerguelen Islands and its link with the history of species dispersal and establishment under various climatic and ecological conditions.

\section{Conclusion and perspectives}

The obtained results on genome size of several species from the native Kerguelen flora contributed to fill the important lack of knowledge on their cytogenetic variability. In addition, our results support the fact that a majority of species of this flora, having established on Kerguelen across a period of several million years at least for some taxa (Lehnebach et al. 2017; Winkworth et al. 2015; Bartish et al. 2012; Van der Putten et al. 2010; Wagstaff and Hennion 2007) are polyploids. This observation is in agreement with what has been observed for species of high latitudes in the Northern Hemisphere but also in the Falkland Islands and South Georgia in the sub-Antarctic. These data did not allow us to highlight a strong variability in genome size at the intraspecific level except for Lyallia kerguelensis and Colobanthus kerguelensis. Further analyses on a larger sample of populations are therefore 
450

451

452

453

454

455

456

457

458

459

460

461

462

463

464

465

466

467

468

469

470

471

472

473

474

475

476

477

478

479

480

necessary to better quantify this variability and explore its relationship with the ecological and spatial distribution of these species in Kerguelen. Comparison of polyploidy frequency between Arctic and Antarctic floras is essential to better understand the role of polyploidy in plant adaptation to such extreme environments.

\section{Authors' contributions:}

S.S-Y. and F.H. conceived the ideas. F.L., F.H. and T.R. collected the samples. S.S-Y., N.V. and N.T. performed the flow cytometry measurement. F.H. cultivated the plants in the field and in the laboratory in Rennes and F.H. and V.G. collected and treated the root samples for karyology. S.S.Y. performed the chromosome counts. T.R. performed data analysis. S.S-Y. wrote the manuscript with contributions from T.R., F.H. and N.T. All the authors read and approved the manuscript. SS-Y, TR and FH revised the manuscript following comments from the Editor and three reviewers.

\section{Compliance with ethical standards}

Conflict of interest: The authors declare that they have no conflict of interest

\section{References}

Abdeddaim-Boughanmi K, Garnatje T, Vitales D, Brown C S, Harche-Kaïd M, Siljak-Yakovlev S (2019) A single species, two basic chromosomal numbers: case of Lygeum spartum (Poaceae). Plant biosys 153:775-783. https://doi.org/10.1080/11263504.2018.1549608

Bartish IV, Ainouche A, Jia D, Bergstrom D, Chown SL, Winkworth RC, Hennion F (2012) Phylogeny and colonization history of Pringlea antiscorbutica (Brassicaceae), an emblematic endemic from the South Indian Ocean Province. Mol Phylogenet Evol 65:748-756. https://doi.org/10.1016/j.ympev.2012.07.023

Beaulieu JM, Leitch IJ, Patel S, Pendharkar A, Knight CA (2008) Genome size is a strong predictor of cell size and stomatal density in angiosperms. New Phytol 179: 975-986. https://doi.org/10.1111/j.1469-8137.2008.02528.x

Bennett MD (1972) Nuclear DNA content and minimum generation time in herbaceous plants. Proc R Soc Lond B Biol Sci 181:109135.https://doi.org/10.1098/rspb.1972.0042

Bennett MD (1987) Variation in genomic form in plants and its ecological implications. New Phytol 106: 177-200. https://doi.org/10.1111/j.1469-8137.1987.tb04689.x

Bennett MD, Bhandol P, Leitch I (2000) Nuclear DNA amounts in angiosperms and their modern uses - 807 new estimates. Ann Bot 86:859-909. https://doi.org/10.1006/anbo.2000.125

Bennett MD, Leitch IJ (2005) Nuclear DNA amounts in angiosperms: progress, problems, prospects. Ann Bot-London. 95:45-90. https://doi.org/10.1093/aob/mci003

Bennett MD, Smith JB, Lewis Smith RI (1982) DNA amounts of angiosperms from the Antarctic and South Georgia. Env Exp Bot 22:307-318. https://doi.org/10.1016/00988472(82)90023-5 
Bergstrom DM, Bricher PK, Raymond B, Terauds A, Doley D, McGeoch MA, Whinam J, Glen M, Yuan Z, Kiefer K, Shaw DJ, Bramely-Alves J, Rudman T, Mohammed C, Lucieer A, Visoiu M, van Vuuren J, Ball MC (2015) Rapid collapse of a sub-Antarctic alpine ecosystem: the role of climate and pathogens (M Cadotte, Ed.). J Appl Ecol 52:774-783.https://doi.org/10.1111/1365-2664.12436

Blackburn KB (1939) The Limosella plants of Glamorgan. Part II. Chromosome and species. J Bot 77:67-71

Bou Dagher-Kharrat M, Abdel-Samad N, Douaihy BC, Abdel-Samad F, Bourge M, SiljakYakovlev S, Brown S (2013) Nuclear DNA C-values for biodiversity screening: Case of the Lebanese flora. Plant biosys 147:1228-1237. http://dx.doi.org/10.1080/11263504.2013.861530

Bourge M, Brown SC, Siljak-Yakovlev S (2018) Flow cytometry as tool in plant sciences, with emphasis on genome size and ploidy level assessment. Genetics \& Application 2:1-12, https://doi.org/10.31383/ga.vol2iss2pp1-12

Brochmann C, Brysting AK, Alsos IG, Borgen L, Grundt HH, Scheen AC, Elven R (2004) Polyploidy in arctic plants. Biol J Linn Soc 82:521-536. https://doi.org/ 10.1111/j.10958312.2004.00337. $\mathrm{x}$.

Carta A, Peruzzi L (2015) Testing the large genome constraint hypothesis: plant traits, habitat and climate seasonality in Liliaceous. New Phytol 210:709-716. https://doi.org/10.1111/nph.13769

Cerbah M, Coulaud J, Brown SC, Siljak-Yakovlev S (1999) Evolutionary DNA variation in the genus Hypochoeris. Heredity 82: 261-266.https://doi.org/10.1038/sj.hdy.6884690

Chown SL, Rodrigues ASL, Gremmen NJM, Gaston K (2001) World heritage status and conservation of Southern Ocean islands. Conserv Biol 15:550557.https://www.jstor.org/stable/3061434

Cuba-Diaz M, Cerda G, Rivera C, Gomez A (2017) Genome size comparison in Colobanthus quitensis populations show differences in species ploidy. Polar Biol 40:1475-1480. https://doi.org/ 10.1007/s00300-016-2058-z

Dawson MI (2000) Index of chromosome numbers of indigenous New Zealand spermatophytes. New Zea J Bot 38:47-150. https://doi.org/ 10.1080/0028825X.2000.9512673

Doležel J, Bartoš J, Voglmayr H, Greilhuber J (2003) Nuclear DNA content and genome size of trout and human. Cytometry 51:127-129. https://doi.org.10.1002/cyto.a.10013

Doležel J, Greilhuber J, Suda J (2007) Estimation of nuclear DNA content in plants using flow cytometry. Nat Protoc 2(9):2233-2244 https://doi.org/10.1038/nprot.2007.310

Dunn O J (1964) Multiple Comparisons Using Rank Sums. Technometrics 6:241-252

Farhat P, Hidalgo O, Robert T, Siljak-Yakovlev S, Leitch JI, Adams R, Bou Dagher Kharrat M (2019a) Polyploidy in the conifer genus Juniperus: an unexpectedly high rate. Front Plant Sci 10, 676. https://doi.org /10.3389/pls.2019.00676

Farhat P, Siljak-Yakovlev S, Adams PR, Bou Dagher Kharrat M, Robert T (2019b) Genome size variation and polyploidy in the geographical range of Juniperus sabina L. (Cupressaceae). Bot Lett 166:134-143. https://doi.org/10.1080/23818107.2019.1613262 
Frenot Y, Aubry M, Misset MT, Gloaguen JC, Gourret JP, Lebouvier M (1999) Phenotypic plasticity and genetic diversity in Poa annua L. (Poaceae) at Crozet and Kerguelen Islands (subantarctic). Polar Biol 22:302-310. https://doi.org /10.1007/s003000050423

Frenot Y, Lebouvier M, Gloaguen J-C, Hennion F, Vernon Ph, Chapuis J-L (2006) Impact des changements climatiques et de la fréquentation humaine sur la biodiversité des îles subantarctiques françaises. Rev Belge Géo 3:363-371. https ://doi.org /10.4000/belgeo.12097

Fyad-Lameche FZ, Iantcheva A, Siljak-Yakovlev S, Brown SC (2016) Chromosome number, genome size, seed storage protein profile and competence for direct somatic embryo formation in Algerian annual Medicago species. Plant Cell Tiss Org 124:531-540 (PCTOC). http:s//doi.org/10.1007/s11240-015-0912-2

Garnatje T, Vilatersana R, Susanna A, Vallès J, Siljak-Yakovlev S (2004) Contribution to the karyological knowledge of Echinops (Asteraceae, Cardueae) and related genera. Bot Jour Linn Soc 145:337-344

Greilhuber J, Doležel J, Lysak MA, Bennett MD (2005) The origin, evolution and proposed stabilization of the terms genome size and C-value to describe nuclear DNA contents. Ann Bot 95:255-260. https://doi.org/10.1093/aob/mci019

Grime JP, Moworth MA (1982) Variation in genome size - an ecological interpretation. Nature 299:151-153. https://doi.org/10.1038/299151a0

Guerra M 2008. Chromosome numbers in plant cytotaxonomy: concepts and implications. Cytogenet Genome Res 120:339-350. https://doi.org/10.1159/000121083

Guignard MS, Nichols RA, Knell RJ, Macdonald A, Romila CA, Trimmer M, Leitch IJ, Leitch AR (2016) Genome size and ploidy influence angiosperm species' biomass under nitrogen and phosphorus limitation. New Phytol 210:1195-1206. https://doi.org/10.1111/nph.13881

Hair J B, Beuzenberg E J (1960) Contributions to a chromosome atlas of the New Zealand flora 4. Miscellaneous families. New Zeal J Sci 3:432-440

Hajrudinovic A, Siljak-Yakovlev S, Brown SC, Pustahija F, Bourge M, Ballian D, Bogunic F (2015) When sexual meets apomict - genome size, ploidy level and reproduction mode variation of Sorbus aria s.l. and S. austriaca (Rosaceae) in Bosnia and Herzegovina. Ann Bot 116:301-312. https://doi.org/10.1093/aob/mcv093

Hamel JL (1951) Note sur le noyau et les chromosomes somatiques du Pringlea antiscorbutica R.Br. ex Hook. f. Bull Mus Natl Hist Nat 23:548-551

Hennion F (1992) Etude des caractéristiques biologiques et génétiques de la flore endémique des iles Kerguelen. PhD Thesis, Muséum National d'Histoire Naturelle, Paris, 264pp

Hennion F, Couderc H (1992) Cytogenetical study of Pringlea antiscorbutica R. Br. And Ranunculus moseleyi Hook. F. from the Kerguelen Islands. Antarctic Science 4:57-58. https://doi.org/10.1017/S0954102092000117

Hennion F, Couderc H (1993) Cytogenetical variability of Ranunculus species from Iles Kerguelen. Antarct Sci 5:37-40. https://doi.org/10.1017/S0954102093000069

Hennion F, Walton DWH (1997) Ecology and seed morphology of endemic species from Kerguelen phytogeographic zone. Polar Biol 18:229-235. https://doi.org/10.1007/s003000050182 
Hennion F, Fiasson LJ, Gluchoff-Fiasson K (1994) Morphological and phytochemical relationships between Ranunculus species from Iles Kerguelen. Biochem Syst Evol 22:533-542

Hennion F, Bouchereau A, Gauthier C, Hermant M, Vernon P, Prinzing A (2012) Variation in amine composition in plant species: How it integrates macroevolutionary and environmental signals. Amer J Bot 99:36-45. https://doi.org/10.3732/ajb.1100211

Hermant M, Prinzing A, Vernon P, Convey P, Hennion F (2013) Endemic species have highly integrated phenotypes, environmental distributions and phenotype-environment relationships. J Biogeogr 40:1583-1594. https://doi.org/10.1111/jbi.12095

Hidalgo O, Garcia S, Garnatje T, Mumbrú M, Patterson A, Vigo J, Vallès J (2015) Genome size in aquatic and wetland plants: fitting with the large genome constraint hypothesis with a few relevant exceptions. Plant Systematics and Evolution, 301:1927-1936. https://doi.org/10.1007/s00606-015-1205-2

Holm S (1979) A simple sequentially rejective multiple test procedure. Scand J Statist 6: 6570. https://doi.org/10.2307/4615733

Hooker JD (1847) The Botany of the Antarctic Voyage of H.M. discovery ships Erebus and Terror in the years 1839-1843 under the command of Captain Sir James Clarke Ross. Flora Antarctica. II. Ed. Reeve Brothers, London, pp 207-574

Jomelli V, Schimmelpfennig I, Favier V, Mokadem F, Landais A, Rinterknecht V, Bourlès DL, Brunstein D, Verfaillie D, Legentil C, Aumaitre G, Keddadouche K (2018). Glacier extent in sub-Antarctic Kerguelen archipelago from MIS 3 period: Evidence from 36Cl dating. $\quad$ Quaternary $\quad$ Sci $\quad$ Rev $183: 110-123$. https://doi.org/10.1016/j.quascirev.2018.01.008

Kagale S, Robinson SJ, Nixon J, Xiao R, Huebert T, Condie J, Kessler D, Clarke WE, Edger PP, Links MG, Sharpe AG, Parkin IAP (2014) Polyploid Evolution of the Brassicaceae during the Cenozoic Era. Plant Cell 26:2777-2791. https://doi.org/10.1105/tpc.114.126391

Karrat-Souissi A, Siljak-Yakovlev S, Brown SC, Chaib M (2013) Cytogeography of 28 populations of three ploidy levels of Cenchrus ciliaris L. in Tunisia. Folia Geobot 48:95-113. https://doi.org/10.1007/s12224-012-9137-x.

Knight CA, Molinari NA, Petrov DA (2005) The large genome constraint hypothesis: evolution, ecology and phenotype. Ann Bot (Oxford) 95:177-190. https://doi.org/10.1093/aob/mci011

Labarrere B, Prinzing A, Dorey T, Chesneau E, Hennion F (2019) Variations of secondary metabolites among natural populations of sub-Antarctic Ranunculus species suggest functional redundancy and versatility. Plants 8(7): 234. https://doi.org/10.3390/plants8070234

Leitch IJ MW Chase, Bennett MD (1998) Phylogenetic analysis of DNA C gains provides evidence for a small ancestral genome size in flowering plants. Ann Bot 82 (Suppl A.): 85-94. https://doi.org/0305-7364/98/0A0085+ 10

Lehnebach C., Winkworth RC, Becker M, Lockhart PJ, Hennion F (2017) Around the pole: evolution of sub-Antarctic Ranunculus. J Biogeogr 44:875-886. https://doi.org/10.1111/jbi.12952 
Lepers-Andrzejewski S, Siljak-Yakovlev S, Brown SC, Wong M, Dron M (2011) Diversity and dynamics of plant genome size:an example of polysomaty from a cytogenetic study of Tahitian Vanilla (Vanillaxtahitensis, Orchidaceae). Am J Bot 98:986-997. https://doi.org/10.3732/ajb.1000415

Le Roux PC, McGeoch MA, Nyakatya MJ, Chown SL (2005) Effects of a short-term climate change experiment on a sub-Antarctic keystone plant species. Global Change Biol 11: 1628-1639. https://doi.org/10.1111/j.1365-2486.2005.001022.x

Löve A, Löve D (1958) The American element in the flora of the Brithish Isles. Bot Notiser 111:376-388

Lysak MA, Berr A, Pecinka A, Schmidt R, McBreen K, Schubert I (2006) Mechanisms of chromosome number reduction in Arabidopsis thaliana and related Brassicaceae species. PNAS March 28, 103 5224-5229. https://doi.org/10.1073/pnas.0510791103

Marie D, Brown SC (1993) A cytometric exercise in plant DNA histograms, with 2C values for 70 species. Biol Cell 78:41-51. https://doi.org/10.1016/0248-4900(93)90113-s

Niketic M, Siljak-Yakovlev S, Frajman B, Lazarevic M, Stevanovic B, Tomovic G, Stevanovic V (2013) Towards resolving the systematics of Cerastium subsect. Cerastium (Caryophyllaceae): a cytogenetic approach. Bot Jour Linn Soc 172: 205-224. https://doi.org/10.1111/boj.12050

Nicolaysen K, Frey FA, Hodges KV, Weis D, Giret A (2000) 40Ara39Ar geochronology of £ood basalts from the Kerguelen Archipelago, southern Indian Ocean: implications for Cenozoic eruption rates of the Kerguelen plume. Earth Planet Sci Lett: 174:313. 328. https://doi.org/10.1016/s0012-821x(99)00271-x

Oron AP, Hoff PD (2006) Kruskal-Wallis and Friedman type tests for nested effects in hierarchical designs. Centre for statistics and the social science, University of Washington

Pellicer J, Leitch I (2014) The Application of flow cytometry for estimating genome size and ploidy level in plants. In: Besse, P. (ed.) Molecular plant taxonomy: methods and protocols. Springer Science+Business Media New York. Meth Molec Biol 1115:279307. https://doi.org/10.1007/978-1-62703-767-9_14

Pellicer J, Hidalgo O, Dodsworth S, Leitch IJ (2018) Genome size diversity and its impact on the evolution of land plants. Genes 9:88. https://doi.org.10.3390/genes9020088

Petrov DA (2001) Evolution of genome size: new approaches to an old problem. Trends in Genetics 17:23-28. https://doi.org/10.1016/S0168-9525(00)02157-0

Petrov DA (2002) Mutational equilibrium model of genome size evolution. Theor Popul Biol, 61:531-544. https://doi.org/10.1006/tpbi.2002.1605

Price HJ, Johnston SJ (1996) Influence of light on DNA content of Helianthus annuus Linnaeus. Proc Natl Acad Sci USA 93:11264-11267. https://doi.org/10.1073/pnas.93.20.11264

Pustahija F, Brown CS, Bogunic F, Basic N, Muratovic E, Ollier S, Hidalgo O, Bourge M, Stevanović V, Siljak-Yakovlev S (2013) Small genomes dominate in plants growing on serpentine soils in West Balkans, an exhaustive study of 8 habitats covering 308 taxa. Plant soil 373:427-453. https://doi.org/10.1007/s11104-013-1794-x 
Razafinarivo NJ, Rakotomalala JJ, Brown SC, Bourge M, Hamon S, Kochko A de, Poncet V, Dubreuil-Tranchant C, Couturon E, Guyot R, Hamon P (2012) Geographical gradients in the genome size variation of wild coffee trees (Coffea) native to Africa and Indian Ocean islands. Tree Genet Genomes 8:1345-1358. https://doi.org/10.1007/s11295-0120520-9

Rollins RC, Rüdenberg L (1971) Chromosome numbers of Cruciferae. II. Contr. Gray Herb. 201: 117-133

Siljak-Yakovlev S, Stevanovic V, Tomasevic M, Brown S, Stevanovic B (2008) Genome size variation and polyploidy in the resurrection plant genus Ramonda: cytogeography of living fossils. Env Exp Bot 62:101-112. https://doi.org/10.1016/j.envexpbot.2007.07.017

Siljak-Yakovlev S, Pustahija F, Šolić EM, Bogunić F, Muratović E, Bašić N, Catrice O, Brown CS (2010) Towards a database of genome size and chromosome number of Balkan flora: C-values in 343 taxa with novel values for 252. Adv Sci Lett (U.S.A.) 3:190-213. https://doi.org/10.1166/asl.2010.1115

Siljak-Yakovlev S, Farhat P, Valentin N, Bareka P, Kamari G (2019) New estimates of nuclear DNA amount for 25 taxa from Cephalonia flora which $\mathrm{xx}$ are endemics. Bot Chron 22: 87-108

Smith RIL (1984) Terrestrial plant biology of the sub-Antarctic and Antarctic. In R.M. Laws, ed. Antarctic ecology. Academic Press, London, vol. 1, p 61-162

Soltis P S, Soltis D E (2009). The role of hybridization in plant speciation. Annu Rev Plant Biol 60:561-588. https://doi.org/ 10.1146/annurev.arplant.043008.092039

Srisuwan S, Sihachakr D, Martin J, Valles J, Brown SC, Siljak-Yakovlev S (2019) Change in nuclear DNA content and pollen size during polyploidisation of the sweet potato Ipomoea batatas (Convolvulaceae) complex. Plant Biol 21:237-247. https://doi.org/10.1111/plb.12945

Suda J, Weiss-Schneeweiss H, Tribsch A, Schneeweiss GM, Trávníček P, Schönswetter P (2007) Complex distribution patterns of Di-, tetra-, and hexaploid cytotypes in the European high mountain plant Senecio carniolicus (Asteraceae). Am J Bot 94:13911401. https://doi.org/10.3732/ajb.94.8.1391

Swift H (1950) The constancy of deoxyribose nucleic acid in plant nuclei. P Natl Acad SciBiol 36:643-654. PMCID: PMC1063260

Šmarda P, Bureš P (2006) Intraspecific DNA content variability in Festuca pallens on different geographical scales and ploidy levels. Ann Bot 98:665-678. https://doi.org/ 10.1093/aob/mcl150

Šmarda P, Horová L, Bureš P, Hralová I, Marková M (2010) Stabilizing selection on genome size in a population of Festuca pallens under conditions of intensive intraspecific competition. New Phytol 187:1195-1204. https://doi.org/ 10.1111/j.14698137.2010.03335.x

Šmarda P, Hejcman M, Březinová A, Horová L, Steigerová H, Zedek F, Bureš P, Hejcmanová P, Schellberg J (2013) Effect of phosphorus availability on the selection of species with different ploidy levels and genome sizes in a long-term grassland fertilization experiment. New Phytol 200:911-921. https://doi.org/ 10.1111/nph.12399

Van de Peer Y, Mizrachi E, Marchal K (2017) The evolutionary significance of polyploidy. Nat Rev Genet 18:1-14. https://doi.org/10.1038/nrg.2017.26 
Van der Putten N, Verbruggen C, Ochyra R, Verleyen E, Frenot Y (2010) Subantarctic flowering plants: pre-glacial survivors or post-glacial immigrants? J Biogeogr 37:582592. https://doi.org/10.1111/j.1365-2699.2009.02217.x

Vekemans X, Lefebvre C, Coulaud J, Blaise S, Siljak-Yakovlev S (1996) Variation of nuclear DNA content at the species level in Armeria maritima (Mill.) Willd. Hereditas 124:237242. https://doi.org/10.1111/j.1601-5223.1996.00237.x

Wagstaff SJ, Hennion F (2007) Evolution and biogeography of Lyallia and Hectorella (Portulacaceae), geographically isolated sisters from the Southern Hemisphere. Antarct Sci 19:417-426. https://doi.org/10.1017/S0954102007000648

Waltari E, Edwards SV (2002) Evolutionary dynamics of intron size, genome size, and physiological correlates in archosaurs. Am Nat 160:539-552. http://dx.doi.org/10.1086/34207

Werth E (1911) Die Vegetation der Subantarktischen Inseln Kerguelen, Possession - und Heard-Eiland, Teil 2. In: Drygalski Ev(Ed) Deutsche Südpolar-Expedition 1901-1903, Botanik Heft 3, pp 125-371

Winkworth RC, Hennion F, Prinzing A, Wagstaff SJ (2015) Explaining the disjunct distributions of austral plants: the roles of Antarctic and direct dispersal routes. J Biogeogr 42:1197-1209. https://doi.org/10.1111/jbi.12522

\section{Figure captions}

Fig. 1 Plant material collection sites in Kerguelen Islands

Fig. 2 Metaphase chromosome plates: A. Colobanthus kerguelensis $(2 n=80)$, B. Lyallia kerguelensis $(2 n=96)$, and C. Limosella australis $(2 n=60)$. Bar $=10 \mu \mathrm{m}$

Fig. 3 Cytometric histograms for ten studied species 


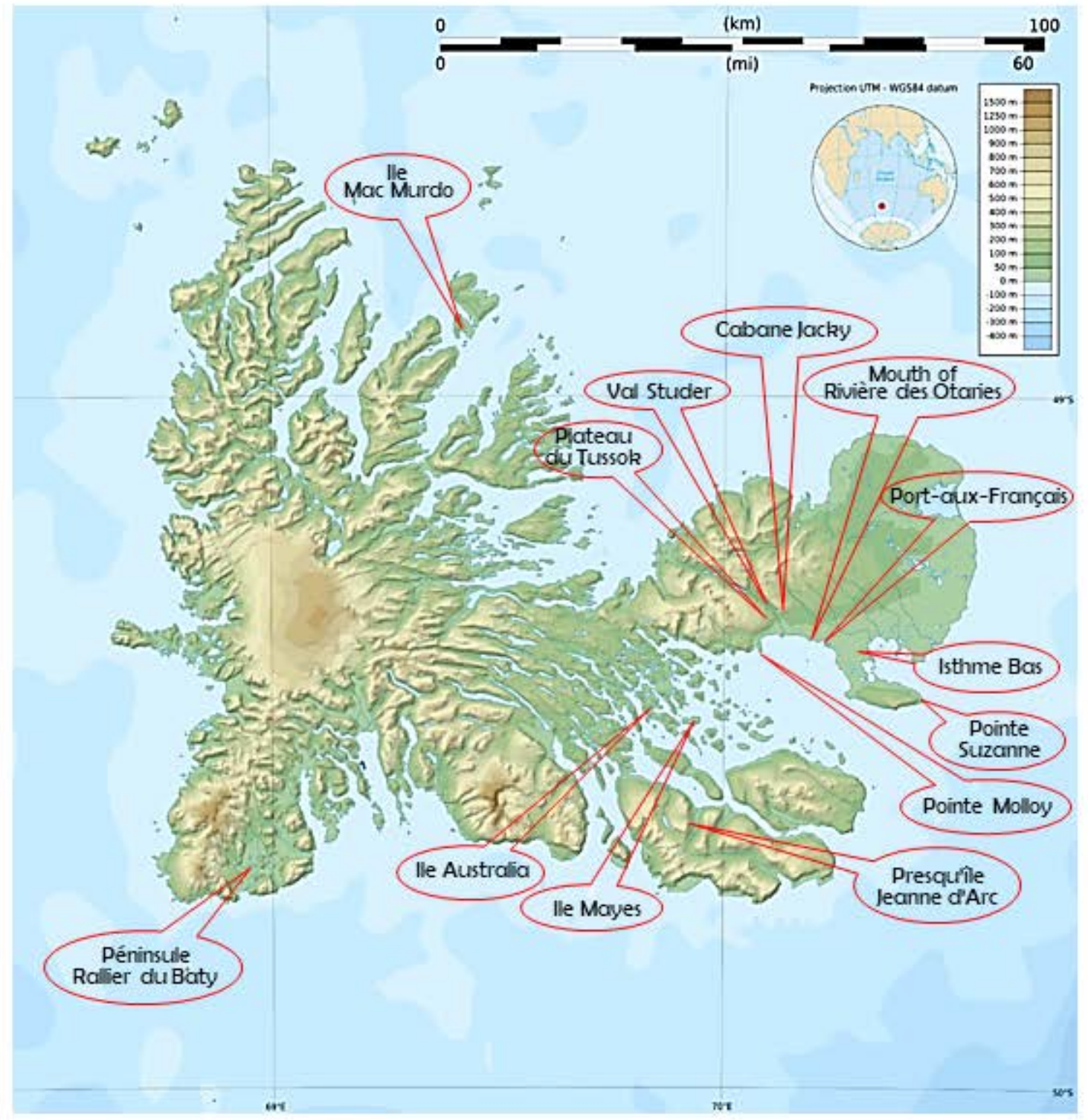




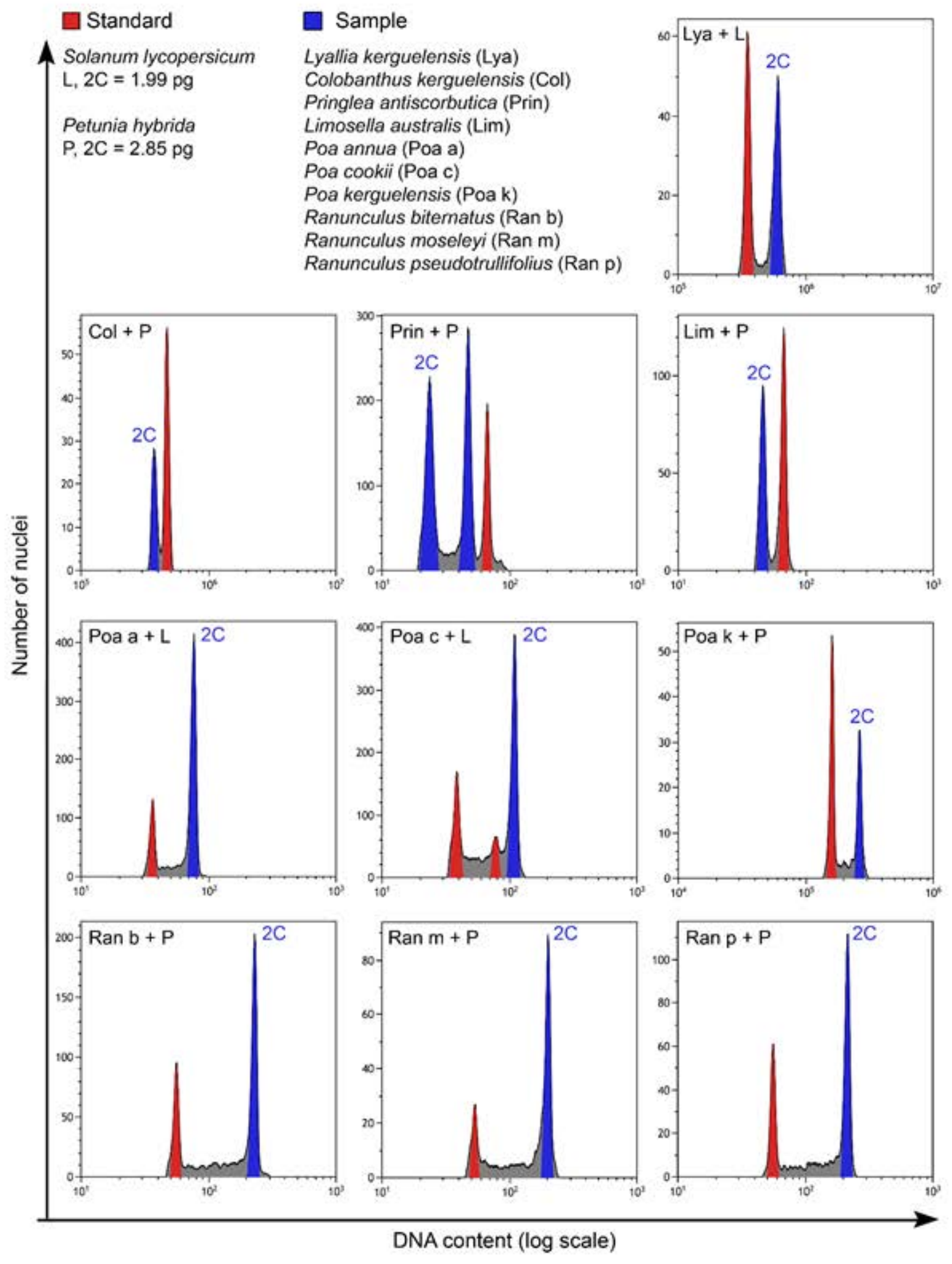



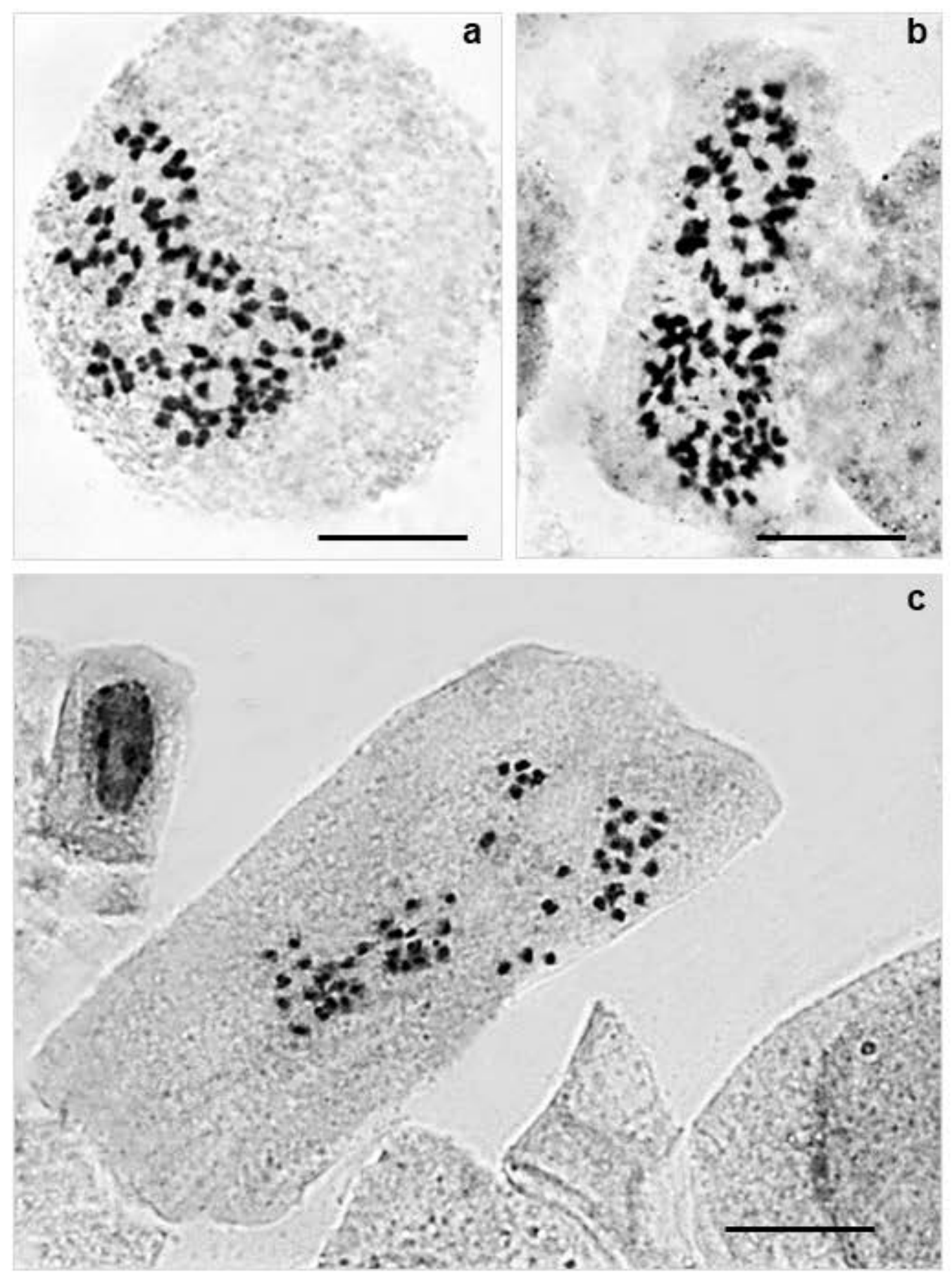
Table 1 Origin of investigated populations with localities, GPS coordinates and year of collection

\begin{tabular}{|c|c|c|c|c|}
\hline Species/Population & $\begin{array}{c}\text { Geographical } \\
\text { range }\end{array}$ & Locality & $\begin{array}{c}\text { GPS } \\
\text { coordinates }\end{array}$ & Campagne \\
\hline $\begin{array}{l}\text { Colobanthus kerguelensis Hook.f. } \\
\text { (Caryophyllaceae) }\end{array}$ & $\begin{array}{l}\text { endemic to } \\
\text { SIOP }\end{array}$ & & & \\
\hline IB & & Isthme-Bas & $-49.3872 ; 70.27326$ & 2016-17 \\
\hline CAJ & & Cabane Jacky & $-49.3134 ; 70.1234$ & 2016-17 \\
\hline TUS & & Plateau du Tussok & $-49.2967 ; 70.04608$ & $2016-17$ \\
\hline RBA-10 & & Péninsule Rallier du Baty & $-49.6601 ; 68.9797$ & 2017-18 \\
\hline $\mathrm{SUZ}^{*}$ & & Pointe Suzanne & n.a. & Avril 2017 \\
\hline $\begin{array}{l}\text { Limosella australis R.Br. } \\
\text { (Scrophulariaceae) }\end{array}$ & wide, native & & & \\
\hline PJDA3 & & Péninsule Jeanne d'Arc & $-49.52387 ; 70.15679$ & 2015-16 \\
\hline $\begin{array}{l}\text { Lyallia kerguelensis Hook.f. } \\
\text { (Montiaceae) }\end{array}$ & strict endemics & & & \\
\hline AUS-23 & & south of Ile Australia & $-49.4646 ; 69.8769$ & 2015-16 \\
\hline MAY-2 & & Ile Mayes & $-49.47404 ; 69.93306$ & 2016-17 \\
\hline MAC-3 & & Ile Mac Murdo & $-48.89503 ; 69.41626$ & 2017-18 \\
\hline AUS-25* & & south of Ile Australia & $-49.46568 ; 69.87563$ & March 2019 \\
\hline AUS-30* & & south of Ile Australia & $-49.47672 ; 69.89263$ & March 2019 \\
\hline Poa annua L. (Poaceae) & wide, & & & \\
\hline AUS-N & introduced & north of Ile Australia & $-49.43579 ; 69.84936$ & 2016-17 \\
\hline $\mathrm{PAF}^{*}$ & & Port-aux- Français & $-49.3526 ; 70.2170$ & 2016-17 \\
\hline STU-7 & & Val Studer & n.a. & 2015-16 \\
\hline MOL & & Pointe Molloy & $-49.3523 ; 70.07608$ & 2016-17 \\
\hline P. cookii (Hook.f.) Hook.f. & $\begin{array}{l}\text { endemic to } \\
\text { SIOP }\end{array}$ & & & \\
\hline AUS-N & & north of Ile Australia & $-49.4387 ; 69.8496$ & 2016-17 \\
\hline MAC 4 & & Ile Mac Murdo & $-48.8877 ; 69.4199$ & 2017-18 \\
\hline AUS-S & & south of Ile Australia & $-49.47223 ; 69.89118$ & 2015-16 \\
\hline $\begin{array}{l}\text { P. kerguelensis ( } \underline{\text { Hook.f.) Steud. }} \\
\text { AUS-N }\end{array}$ & $\begin{array}{l}\text { endemic to } \\
\text { SIOP }\end{array}$ & north of Ile Australia & -49.43973; 69.85439 & 2016-17 \\
\hline IB & & Isthme-Bas & n.a. & 2016-17 \\
\hline PAF & & Near to Port-aux-Français & $-49.3227 ; 70.1768$ & 2016-17 \\
\hline CAJ & & Cabane Jacky & $-49.3132 ; 70.1233$ & 2016-17 \\
\hline
\end{tabular}

Pringlea antiscorbutica $\underline{\text { R.Br. }}$ ex Hook.f. (Brassicaceae)

AUS-N endemic to

SIOP 


\begin{tabular}{|c|c|c|c|c|}
\hline CAJ & & Cabane Jacky & $-49.3124 ; 70.1239$ & 2016-17 \\
\hline TUS & & Plateau du Tussok & n.a. & 2016-17 \\
\hline $\begin{array}{l}\text { Ranunculus biternatus Sm. } \\
\text { (Ranunculaceae) }\end{array}$ & $\begin{array}{l}\text { circumpolar } \\
\text { area }\end{array}$ & & & \\
\hline AUS-N & & north of Ile Australia & $-49.43211 ; 69.83792$ & 2016-17 \\
\hline IB-13 & & Isthme-Bas & $-49.3818 ; 70.2752$ & 2016-17 \\
\hline IB-2 & & Isthme-Bas & $-49.3843 ; 70.2590$ & 2016-17 \\
\hline R. moseleyi Hook.f. & strict endemic & & & \\
\hline AUS-N5 & & north of Ile Australia & $-49.4216 ; 69.8239$ & 2016-17 \\
\hline IB-2 & & Isthme Bas & $-49.3843 ; 70.2590$ & 2016-17 \\
\hline PAF-5 & & Port-aux-Français & $-49.3352 ; 70.2265$ & 2016-17 \\
\hline $\begin{array}{l}\text { R. pseudotrullifolius Skottsb. } \\
\text { AUS-N6 }\end{array}$ & $\begin{array}{l}\text { Magellanic and } \\
\text { Kerguelen }\end{array}$ & north of Ile Australia & $-49.4497 ; 69.8642$ & 2016-17 \\
\hline IB-1 & & $\begin{array}{l}\text { Isthme-Bas } \\
\text { mouth of Rivière des }\end{array}$ & $-49.3849 ; 70.2752$ & 2016-17 \\
\hline OTA-1 & & Otaries & $-49.3456 ; 70.1654$ & 2016-17 \\
\hline
\end{tabular}

Site abbreviations: AUS: Ile Australia; CAJ: Cabane Jacky; IB: Isthme-Bas; MAY: Ile Mayes; MAC: Ile Mac Murdo; MOL: Pointe Molloy; OTA: mouth of Rivière des Otaries; PAF: Port-auxFrançais; PJDA: Presqu'île Jeanne d’Arc; RBA: Péninsule Rallier du Baty. STU: Val Studer. SUZ: Pointe Suzanne; TUS: Plateau du Tussok. Name of site is followed by population number. SIOP: South Indian Ocean Province

* population used only for chromosome counting 
Table 2 Genome size (2C DNA in pg and 1C DNA in Mbp), chromosome number and ploidy level of ten species from Kerguelen Islands

\begin{tabular}{|c|c|c|c|c|c|c|c|}
\hline Species/Population & $\begin{array}{c}\text { 2C DNA } \\
\text { in pg } \\
\text { (range) }\end{array}$ & $\begin{array}{c}\text { 1C } \\
\text { DNA } \\
\text { in Mbp } \\
\end{array}$ & $\mathbf{N}$ & S & 2n (ploidy) & $\begin{array}{c}\text { P-value } \\
\$ \\
\end{array}$ & $\begin{array}{l}\text { Signif. } \\
\text { level § }\end{array}$ \\
\hline Colobanthus kerguelensis & & & & & $80(8 x)$ & & \\
\hline 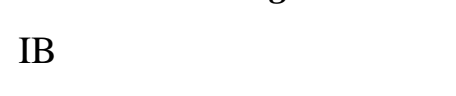 & $\begin{array}{c}2.42^{\mathbf{b}} \\
(2.28-2.57)\end{array}$ & 1183 & 5 & $\mathrm{P}$ & & & \\
\hline CAJ & $\begin{array}{c}2.39 \\
(2.36-2.48)\end{array}$ & 1169 & 5 & & & & \\
\hline TUS & $\begin{array}{c}2.38 \\
(2.34-2.44)\end{array}$ & 1164 & 5 & & & & \\
\hline RBA-10 & $\begin{array}{c}2.26 \\
(2.21-2.34)\end{array}$ & 1105 & 6 & & & & \\
\hline Means (SD) for species & $2.41(0.08)^{\mathrm{C}}$ & 1178 & 21 & & & 0.009 & $* *$ \\
\hline Limosella australis & & & & & $60(6 x)$ & & \\
\hline PJDA3 & 1.91 & 934 & 1 & $\mathrm{P}$ & & & \\
\hline Lyallia kerguelensis & & & & & $96(8 x)$ & & \\
\hline AUS-23 & $\begin{array}{c}3.18 \\
(3.08-3.20)\end{array}$ & 1555 & 5 & $S$ & & & \\
\hline MAY-2 & $\begin{array}{c}3.21 \\
(3.14-3.42)\end{array}$ & 1569 & 5 & & & & \\
\hline MAC-3 & $\begin{array}{c}2.97 \\
(2.75-3.17)\end{array}$ & 1452 & 5 & & & & \\
\hline Means (SD) for species & $3.13(0.21)$ & 1526 & 15 & & & 0.014 & $*$ \\
\hline Poa annua & & & & & $28(4 x)$ & & \\
\hline AUS-N & $\begin{array}{c}4.16 \\
(4.12-4.21)\end{array}$ & 2034 & 6 & $\mathrm{H}$ & & & \\
\hline STU-7 & $\begin{array}{c}4.16 \\
(4.12-4.27)\end{array}$ & 2034 & 5 & & & & \\
\hline MOL & $\begin{array}{c}4.26 \\
(4.13-4.29)\end{array}$ & 2083 & 5 & & & & \\
\hline Means (SD) for species & $4.19(0.06)$ & 2049 & 16 & & & 0.146 & NS \\
\hline Poa cookii & & & & & $28(4 x)^{\mathbf{d}}$ & & \\
\hline AUS-N & $\begin{array}{c}5.70 \\
(5.45-5.89)\end{array}$ & 2787 & 5 & $\mathrm{H}$ & & & \\
\hline MAC-4 & $\begin{array}{c}5.80 \\
(5.30-5.87)\end{array}$ & 2836 & 5 & & & & \\
\hline AUS-1 & $\begin{array}{c}5.67 \\
(5.60-5.96)\end{array}$ & 2772 & 4 & & & & \\
\hline Means (SD) for species & $5.72(0.18)$ & 2797 & 14 & & & 0.914 & NS \\
\hline Poa kerguelensis & & & & & $28(4 x)$ & & \\
\hline AUS-N & $\begin{array}{c}4.99 \\
(4.97-5.15)\end{array}$ & 2440 & 5 & $\mathrm{H}$ & & & \\
\hline PAF & $\begin{array}{c}5.02 \\
(4.96-5.14)\end{array}$ & 2454 & 5 & & & & \\
\hline
\end{tabular}




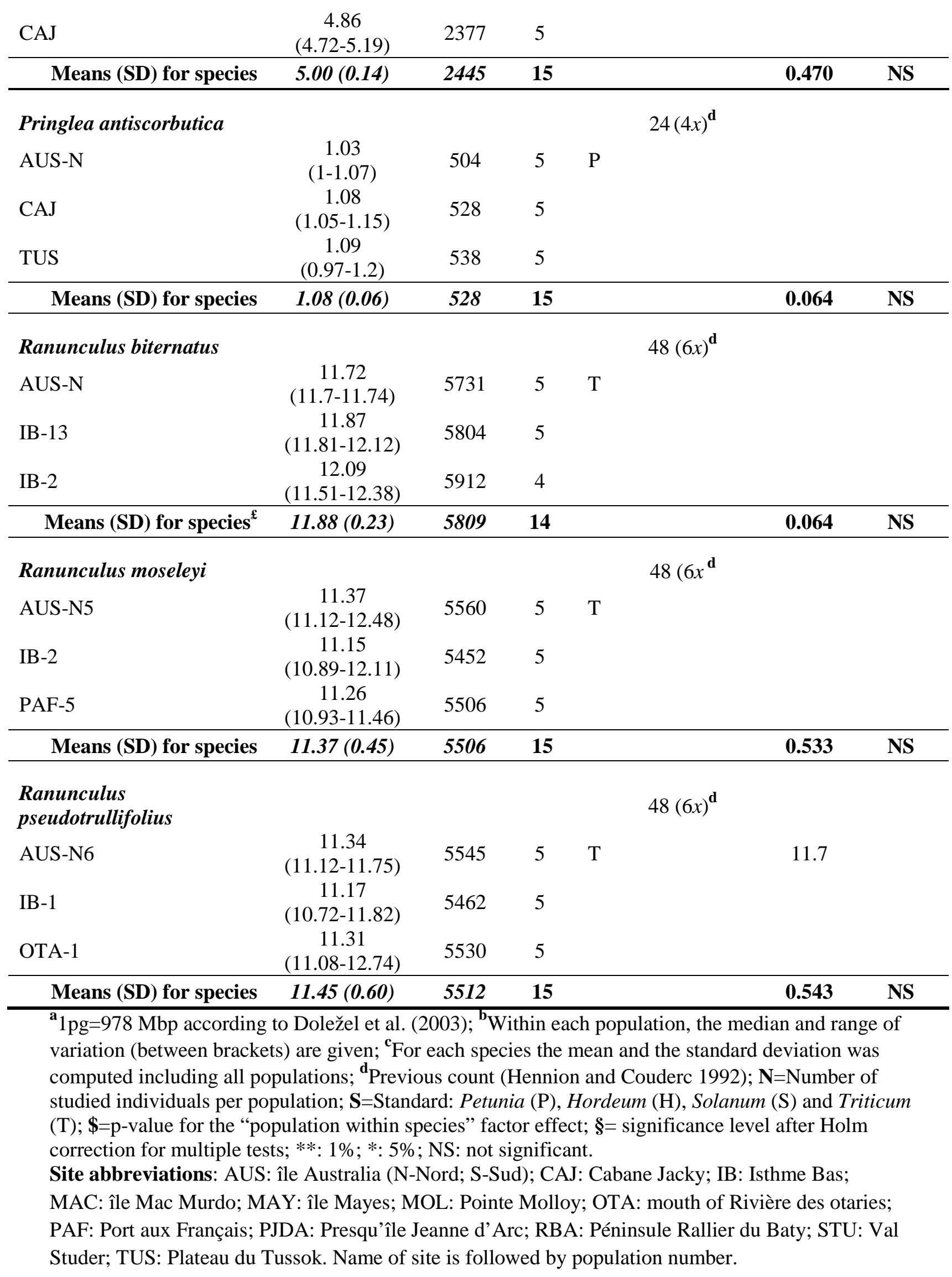

